\title{
Transcriptome landmarks of the functional maturity of rat beta-cells, from lactation to adulthood
}

\author{
Carlos Larqué1, Myrian Velasco1, Francisco Barajas-Olmos², Neyvis García-Delgado', \\ Juan Pablo Chávez-Maldonado', Jazmín García-Morales', Lorena Orozco² and \\ Marcia Hiriart ${ }^{1}$
}

1Department of Neurodevelopment and Physiology, Neuroscience Division, Instituto de Fisiología Celular, Universidad Nacional Autónoma de México, Mexico City, Mexico

2Immunogenomics and Metabolic Disease Laboratory, Instituto Nacional de Medicina Genómica, SS, Mexico City, Mexico

Correspondence should be addressed to M Hiriart Email

mhiriart@ifc.unam.mx

\begin{abstract}
Research on the postnatal development of pancreatic beta-cells has become an important subject in recent years. Understanding the mechanisms that govern beta-cell postnatal maturation could bring new opportunities to therapeutic approaches for diabetes. The weaning period consists of a critical postnatal window for structural and physiologic maturation of rat beta-cells. To investigate transcriptome changes involved in the maturation of beta-cells neighboring this period, we performed microarray analysis in fluorescence-activated cell-sorted (FACS) beta-cell-enriched populations. Our results showed a variety of gene sets including those involved in the integration of metabolism, modulation of electrical activity, and regulation of the cell cycle that play important roles in the maturation process. These observations were validated using reverse hemolytic plaque assay, electrophysiological recordings, and flow cytometry analysis. Moreover, we suggest some unexplored pathways such as sphingolipid metabolism, insulin-vesicle trafficking, regulation of transcription/transduction by miRNA-30, trafficking proteins, and cell cycle proteins that could play important roles in the process mentioned above for further investigation.
\end{abstract}

\section{Key Words}

- beta-cell maturation

- beta-cell cycle

- GSEA

- insulin-vesicle-trafficking

- beta-cell FACS

- insulin secretion

- systems biology

\section{Introduction}

Pancreatic beta-cells secrete insulin in response to changes in extracellular glucose and other secretagogues and are considered a metabolic milestone involved in regulating not only glucose but also other nutrient levels such as amino acids and lipids in the body. Postnatal development of pancreatic beta-cells has become an important subject of research in recent years not only for the achievement of the capability to differentiate progenitor or reprogramed cells into insulin-secreting cells (Mayhew \& Wells 2010, Schroeder 2012, Kumar et al. 2014) but also to control beta-cell proliferation and maturation as a therapeutic approach in diabetes. Earlier work has suggested that cells that produce and secrete insulin can be generated using a variety of strategies (Sena et al. 2010, Vetere et al. 2014). http://jme.endocrinology-journals.org DOI: 10.1530/JME-16-0052
C) 2016 Society for Endocrinology Printed in Great Britain 
These insulin-secreting cells, produced in vitro, have characteristics similar to those of beta-cells, such as insulincontaining granules, and express beta-cell-related genes. However, these cells show a lower glucose-stimulated insulin secretion (GSIS) response or transcriptome differences compared with completely developed, normal beta-cells (D'Amour et al. 2006, Hrvatin et al. 2014, Narayanan et al. 2014, Pagliuca et al. 2014).

Previous work in our laboratory demonstrated that the rat islet development shows a critical postnatal window during the weaning period (Aguayo-Mazzucato et al. 2006). In accordance, it had been proposed that the mature beta-cell phenotype is determined by the capability to secrete robust amounts of insulin in basal conditions (between 4.5 and $5.6 \mathrm{mM}$ glucose) and increase their insulin secretion in a correlated manner with stimulating glucose concentrations $(>7 \mathrm{mM})$ (Hiriart \& Aguilar-Bryan 2008). It has been suggested that the beta-cell maturation process involves changes in expression levels of ion channels related to insulin secretion (Navarro-Tableros et al. 2007b) and structural changes within the islet per se, and the islet vasculature and innervation (Cabrera-Vasquez et al. 2009). Furthermore, recent works had compared neonatal and adult rat beta-cell transcriptomes and observed changes in the expression levels of genes that could be involved in the maturation of the GSIS response. These genes include transcription factors such as MafA and NeuroD1; hormone receptors (Glp1r); glycolysis-, and Krebs cycle-related genes, namely Slc2a2, Pfk1, and Pc; metabolism/use of FAD/FMN-related genes (flavin adenine dinucleotide/ flavin mononucleotide), for instance $F m o 5$ and $R f k$; and mitochondrial shuttles-related genes such as Mdh1/2 and Gpd1/2 (Aguayo-Mazzucato et al. 2011, Jermendy et al. 2011, Martens et al. 2014). However, it is possible that RNA obtained from microdissected islets could include gene transcripts from non-beta-cells, as shown by immunostaining, to determine the cell composition of rat islets at different ages (Jermendy et al. 2011). Moreover, it has been suggested that analyses based on differentially expressed genes may overlook effects on cellular processes or signaling pathways (Subramanian et al. 2005). The aim of this work was to determine the physiologic cellular context and the functional changes that could participate in the postnatal maturation process of fluorescence-activated cell sorting (FACS)enriched populations of immature (20d) and mature (adult) rat beta-cells by the assessment of gene-set-based transcriptome analysis.

\section{Materials and methods}

\section{Reagents}

Reagents were obtained from the following sources: Hank's balanced salt solution (HBSS), ethylene glycolbis[ $\beta$-aminoethylether] $N, N, N^{\prime}, N^{\prime}$-tetraacetic acid] (EGTA), Ficoll 400, trypan blue, poly-L-lysine, 4-(2-hydroxyethyl)1-piperazineethanesulfonic acid (HEPES), Staphylococcus aureus protein $\mathrm{A}$, and trypsin from Sigma-Aldrich; collagenase $\mathrm{P}$ from Roche; DMEM salts, penicillinstreptomycin solution, Ham F10 medium, L-glutamine solution, fetal bovine serum (FBS), and guinea pig complement from Life Technologies; bovine serum albumin lyophilized powder (BSA) from United States Biological (Swampscott, MA, USA).

\section{Animals}

The Animal Care Committee of the Instituto de Fisiología Celular, Universidad Nacional Autónoma de México approved all the methods used in this study. Animal care was performed according to the International Guiding Principles for Biomedical Research Involving Animals, Council for International Organizations of Medical Sciences, 2010.

All experiments, except microarray analysis, were carried out in neonatal ( 1 day postnatal), suckling (20 days old), weaning (28 days old), and young adult (250-280 g) Wistar male rats. Animals were obtained from the local animal facility and kept in a $12 \mathrm{~h}$ light: $12 \mathrm{~h}$ darkness cycle. Rats were breast-fed until postnatal day 20, while weaning and young adult rats were fed with standard rat chow composed by Laboratory rodent diet 5001 (LabDiet, St. Louis, MO, USA) since postnatal day 21. Neonatal and suckling rats were fasted $4 \mathrm{~h}$, and weaning and adult rats were fasted $12 \mathrm{~h}$ before experiments.

\section{Islet cell culture}

Before dissection, rats were anesthetized with an intraperitoneal sodium pentobarbital $(40 \mathrm{mg} / \mathrm{kg})$ injection. After surgery, animals were killed by cervical dislocation.

Pancreatic insular cells were obtained following a previously described procedure (Aguayo-Mazzucato et al. 2006). Briefly, pancreatic islets were obtained by collagenase digestion $(0.5 \mathrm{mg} / \mathrm{mL}$ collagenase $\mathrm{P})$ in Hank's balanced salt solution, Ficoll gradient centrifugation (for neonatal islets), and clean-islet handpicking (for suckling, weaning, and adult islets). Insular cells were dissociated by incubating islets in a calcium-free solution

Published by Bioscientifica Ltd. 
with $5.6 \mathrm{mM}$ glucose, $0.5 \%$ BSA, and $3 \mathrm{mM}$ EGTA (ethylene glycol-bis( $\beta$-aminoethylether) $\mathrm{N}, \mathrm{N}, \mathrm{N}^{\prime}, \mathrm{N}^{\prime}$ tetraacetic acid) for $5 \mathrm{~min}$ at $37^{\circ} \mathrm{C}$ in a shaking bath, and 5 min more after trypsin addition (final concentration $0.01 \%$ ), followed by mechanical disruption. Dissociation was stopped when $50-60 \%$ of the cells were observed as single-cell units.

\section{Purification of single beta-cells by FACS}

Before FACS, insular cells were incubated in DMEM supplemented with $0.05 \%$ BSA, $200 \mathrm{U} / \mathrm{mL}$ penicillin $\mathrm{G}$, and $200 \mu \mathrm{g} / \mathrm{mL}$ streptomycin for $45-60 \mathrm{~min}$ at room temperature, and filtered through a $70 \mu \mathrm{m}$ nylon screen to remove large clumps.
Insular cells were washed in isolation medium (123 mM NaCl, $1.8 \mathrm{mM} \mathrm{CaCl}_{2}, 0.8 \mathrm{mM} \mathrm{MgSO}_{4}, 5.4 \mathrm{mM}$ $\mathrm{KCl}, 1 \mathrm{mM} \mathrm{NaH} \mathrm{PO}_{4}, 2.8 \mathrm{mM}$ glucose, $4.2 \mathrm{mM} \mathrm{NaHCO}$, $10 \mathrm{mM}$ HEPES, $0.5 \%$ BSA, $200 \mathrm{U} / \mathrm{mL}$ penicillin $\mathrm{G}$, and $200 \mu \mathrm{g} / \mathrm{mL}$ streptomycin) and sorted using an FACSAria I (Beckton Dickinson) (with blue/red lasers). Purified betacells were received and cultured in Ham F10 medium supplemented with $10 \%$ fetal bovine serum, $200 \mu \mathrm{M}$ L-glutamine, $200 \mathrm{U} /$ penicillin G, $200 \mathrm{mg} / \mathrm{mL}$ streptomycin, and $0.5 \mathrm{mg} / \mathrm{mL}$ amphotericin.

The sorting strategy consisted in gating singlet events in the FSC-H/FSC-A plot; then, gating cells with high autofluorescence at 510-550 $\mathrm{nm}$ wavelength in a FITC-A/FSC-A plot; and finally, selecting cells with high SSC in an SSC-A/FITC-A plot (Fig. 1A).
A

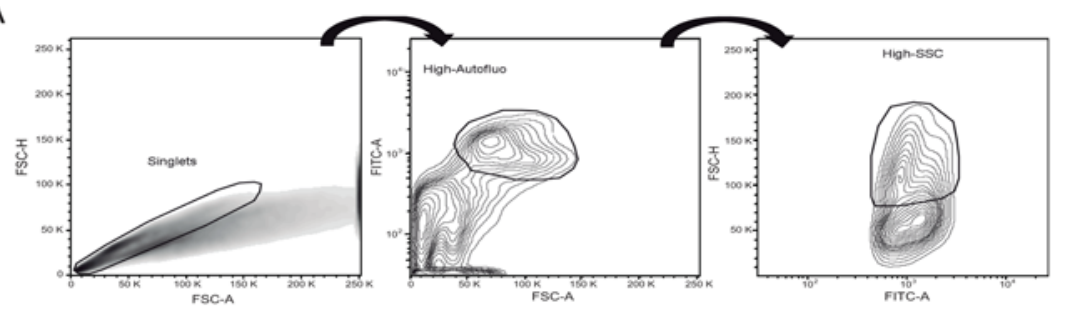

B
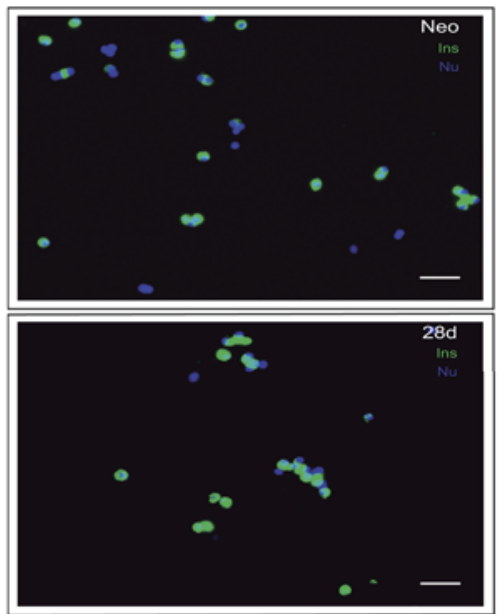

C

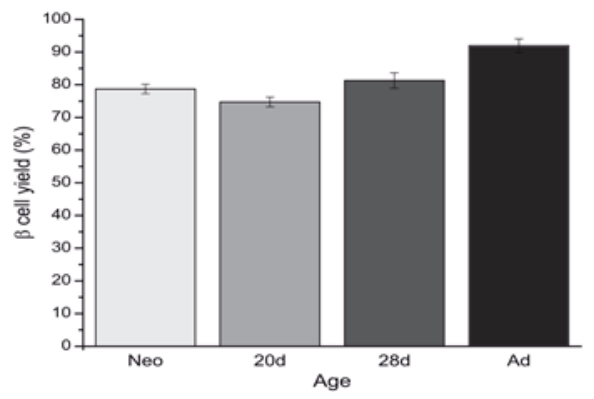

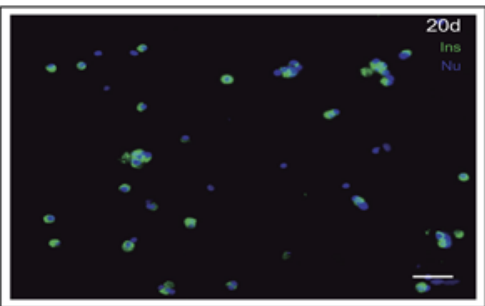

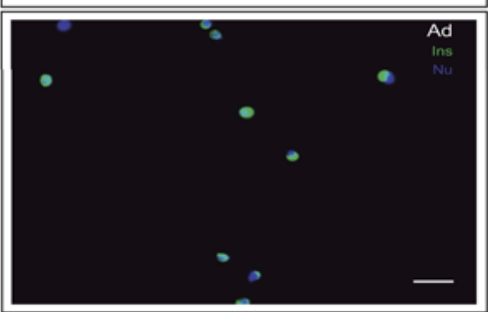

D

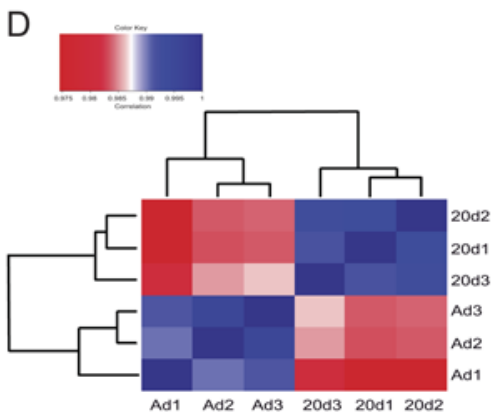

Figure 1

FACS isolation strategy and quantification of enriched beta-cell populations obtained from rats at different postnatal ages. (A) Gating strategy followed to get enriched beta-cell populations by fluorescence-activated cell sorting after primary insular cell culture from neonatal, suckling, weaning, and adult Wistar rats. (B) Insulin (green) immunostaining and nuclear counterstaining (blue) of sorted-cell populations obtained from rats of different ages. (C) Quantification of the beta-cell fraction contained in sorted populations. (D) Heat map and dendrogram that represent the global expression-level correlation among microarrays and the similarity among samples, respectively. Scale bar $=40 \mu \mathrm{m}$. 
Immunofluorescence, purity yield and proliferation assessment

FACS-isolated beta-cells were seeded in previously poly-Llysine-covered coverslips and cultured for $12 \mathrm{~h}$ at $37^{\circ} \mathrm{C}$ and $5 \% \mathrm{CO}_{2}$. Cells were fixed with $2 \%$ paraformaldehyde in PBS for 45 min at room temperature, rinsed with PBS, and permeabilized with a blocking-permeabilizing solution containing $2 \%$ goat serum and $0.1 \%$ Triton X (vol/vol) for $30 \mathrm{~min}$ at room temperature, and incubated overnight at $4^{\circ} \mathrm{C}$ with primary guinea pig antibody anti-insulin at 1:5000 dilution. The next day, cells were incubated for $2 \mathrm{~h}$ with a DyLight 483-conjugated (Jackson ImmunoResearch) or Alexa 649-conjugated (Jackson ImmunoResearch) goat anti-guinea pig IgG antibody (1:200 dilution) at room temperature, and incubated for $10 \mathrm{~min}$ in Hoechst 33342 (Sigma-Aldrich) solution for nuclear counterstaining. Finally, samples were mounted with medium containing $15 \mathrm{mM} \mathrm{NaN}_{3}$ (DAKO). We omitted the incubation with the primary antibody for negative controls.

To analyze proliferation, primary cultured beta-cells from suckling and adult rats were seeded in poly-L-lysinecovered coverslips and cultured for $12 \mathrm{~h}$ at $37^{\circ} \mathrm{C}$ and $5 \%$ $\mathrm{CO}_{2}$. Cells were fixed with $2 \%$ paraformaldehyde in PBS for $30 \mathrm{~min}$ at room temperature, rinsed with $\mathrm{PBS}$, and permeabilized with a blocking-permeabilizing solution containing $10 \%$ goat serum, $0.3 \mathrm{M}$ glycine, $1 \%$ bovine serum albumin, and $0.1 \%$ Tween $(\mathrm{vol} / \mathrm{vol})$ for $1 \mathrm{~h}$ at room temperature, and incubated overnight at $4^{\circ} \mathrm{C}$ with primary rabbit anti-Ki67 (ab15580) and primary guinea pig antibody anti-insulin at 1:100 and 1:5000 dilutions, respectively. The next day, cells were incubated for $1 \mathrm{~h}$ with an FITC (Jackson ImmunoResearch) goat anti-rabbit IgG antibody (1:100 dilution) at room temperature, rinsed with PBS, and incubated for $1 \mathrm{~h}$ with Alexa 649-conjugated goat anti-guinea pig IgG antibody (1:200 dilution) at room temperature. Finally, cells were incubated for $10 \mathrm{~min}$ in Hoechst 33342 solution for nuclear counterstaining and mounted with medium containing $15 \mathrm{mM} \mathrm{NaN}_{3}$ (DAKO). Negative controls were done omitting the incubation with the primary antibodies. Positive controls were done using human cervical cancer cells (SiHa).

For imaging of specific immunoreactivity, cultured beta-cells were viewed under an epifluorescence microscope (Olympus IX7I) equipped with a $100 \mathrm{~W}$ mercury lamp and a filter set appropriate for Hoechst 33342 (excitation/emission wavelengths $365 / 440 \mathrm{~nm}$ ), FITC (excitation/emission wavelengths $488 / 510 \mathrm{~nm}$ ), and Alexa 647 (excitation/emission wavelengths 586/647 nm). Samples were observed with a $20 \times$ objective and a
1.63 zoom. Digital images were acquired with a cooled CCD digital camera (Evolution Media Cybernetics, Silver Spring, MD, USA). Exposures were chosen for the range of fluorescence intensities of each sample. Images were acquired with Image-Pro Express 2.0 software (Media Cybernetics, Silver Spring, MD, USA) and stored in TIFF image format. The beta-cell purity yield was determined by quantifying the insulin-positive cells/total cells relation, and proliferation was determined by quantifying Ki67 positive cells/insulin cells relation with ImageJ NIH, USA, software (http://rsb.info.nih.gov/ij).

\section{RNA extraction, chip hybridization, and microarray data analysis}

Total RNA was extracted using RNeasy Micro Kit (Qiagen) from three independent biological replicates per condition, each consisting of an FACS-isolated beta-cell pool obtained from four young adult or six suckling Wistar rats. Quality control was assessed by an Agilent 2100 Bioanalyzer (Agilent Technologies), taking RIN > 6.4; 200 ng total RNA were labeled and hybridized onto Affymetrix Rat GeneChip Gene 1.0 ST arrays according to manufacturer's instructions, and approximately 16,000 (according to the product data sheet) gene expression levels were obtained. Microarray data were preprocessed using R/Bioconductor software (Gentleman et al. 2004). Background correction, data normalization, and expression calculation were obtained by robust microarray average (RMA) method. Data have been deposited in a MIAME-compliant database (GEO series accession number GSE76969).

Expression data were assessed using gene set enrichment analysis (GSEA) to identify functionally related groups of genes (gene sets) with statistically significant enrichment at each age. Briefly, the data expression profiles from samples of both ages were ranked based on the correlation between their expression and the age distinction, and finally, determining if the members of each a priori defined set of genes are randomly distributed or primarily found at the top or bottom (Subramanian et al. 2005).

In addition, differential expression between both ages was analyzed using the R/Bioconductor package limma (Gentleman et al. 2004). A linear model fit was used, and differentially expressed genes were selected using a cutoff of B-statistic $>0$, and absolute $\log 2$ fold-change $>1.5$.

\section{Reverse hemolytic plaque assay for insulin (RHPA)}

Approximately, 1000 or 2000 FACS-isolated beta-cells were seeded in Cunningham chambers previously treated with

Published by Bioscientifica Ltd. 
poly-L-lysine and incubated for $12 \mathrm{~h}$ at $37^{\circ} \mathrm{C}$ and $5 \% \mathrm{CO}_{2}$ in Ham F10-supplemented medium. Before the experiment, cells were incubated for $45 \mathrm{~min}$ at $37^{\circ} \mathrm{C}$ and $5 \% \mathrm{CO}_{2}$ in Hank's balanced salt solution $5.6 \mathrm{mM}$ glucose; and $0.5 \%$ BSA. A volume of $300 \mu \mathrm{L}$ of a Staphylococcus aureus protein A-coated sheep erythrocytes (1:15 dilution), guinea pig insulin antiserum (1:50 dilution), and guinea pig complement (1:200 dilution) in HBSS solution with $5.6 \mathrm{mM}$ glucose or $15.6 \mathrm{mM}$ glucose were added to Cunningham chambers and cells were incubated for $2 \mathrm{~h}$ at $37^{\circ} \mathrm{C}$ and $5 \% \mathrm{CO}_{2}$. Insulin release was revealed by the presence of hemolytic plaques around cells, which result from the complement-mediated lysis of erythrocytes bearing insulin-anti-insulin complexes bound to protein A.

Each coverslip was scanned with a Leica Micro Dissection System 6000 (version 6.4.1.2887) coupled to a Hitachi HV-D20 camera, and the immunoplaque areas of single cells were measured using ImageJ NIH, USA, software (http://rsb.info.nih.gov/ij).

At least three independent experiments were performed by duplicate and an average of 100 cells was analyzed per experimental condition in each culture.

\section{Cell cycle analysis by flow cytometry}

Cultured insular cells were fixed with $2 \%$ paraformaldehyde in PBS for $45 \mathrm{~min}$ at room temperature, centrifuged and rinsed with PBS twice. After incubating with a blocking-permeabilizing solution containing $2 \%$ goat serum and $0.1 \%$ Triton $\mathrm{X}$ (vol/vol) for $10 \mathrm{~min}$ at room temperature, cells were incubated overnight at $4^{\circ} \mathrm{C}$ with primary guinea pig insulin antiserum at $0.8 \mu \mathrm{L} / 10^{6}$ cells dilution. The next day, cells were incubated for $2 \mathrm{~h}$ with a DyLight 483-conjugated (Jackson ImmunoResearch) goat anti-guinea pig IgG antibody (1:200 dilution) at room temperature, and incubated for $1 \mathrm{~h}$ at room temperature in $1 \mathrm{~mL}$ DAPI (4',6'-diamidino-2-phenylindole) solution $(1 \mu \mathrm{g} / \mathrm{mL})$ in order to label double-stranded DNA. The DNA content of insulin-positive single cells was acquired by an Attune Acoustic Focusing Cytometer (Life Technologies) (with blue/violet lasers), and between 10,000 and 20,000 cells were analyzed with MODFIT software (Verity Software House, Topsham, ME, USA).

\section{Electrophysiology}

Whole-cell configuration of the patch-clamp technique (Hamill et al. 1981) was used to record macroscopic voltagegated $\mathrm{Ca}^{2+}$ currents in isolated beta-cells from suckling (20 days old) and adult rats. Recordings were done at room temperature and using an Axopatch 200A amplifier (Axon Instruments). Patch pipette was pulled from Kimax-51 capillary tube (Kimble Glass, Rockwood, TN, USA) and with resistance of 2-4MOhms when filled with internal solution. Pipette tips were coated with dental wax to reduce pipette stray capacitance. After stable giga-seals were obtained, capacity transients of the pipette were canceled and total cell capacitance was determined by digital integration with $+10 \mathrm{mV}$ pulses; series resistances were compensated using the internal voltage clamp circuitry. Remaining linear capacity transients and leakage currents were subtracted by a $\mathrm{P} / 2$ online procedure. Pulse generation and data acquisition were performed with PClamp software version 8 (Axon Instruments).

The external solution consisted of (in mM) 130 $\mathrm{NaCl}, 5 \mathrm{KCl}, 10 \mathrm{HEPES}, 2 \mathrm{MgCl}_{2}, 5 \mathrm{CaCl}_{2}, 10$ glucose, and $100 \mathrm{nM}$ TTX, pH 7.3. The internal solution contained (in mM) 120 CsAsp, $10 \mathrm{CsCl}, 5 \mathrm{CsF}$, 10 HEPES, 2.5 BAPTA, and 2 ATP, $\mathrm{pH} 7.3$.

The ramp protocol used for the analysis consisted of a depolarizing pulse of $480 \mathrm{~ms}$ duration, from -120 to $120 \mathrm{mV}$, from a holding potential of $-80 \mathrm{mV}$. Graphs show current-voltage relationship between -80 and $60 \mathrm{mV}$.

Finally, we analyzed macroscopic calcium currents of primary cultured beta-cells with capacitances between 4.5 and $11 \mathrm{pF}$ ( $n=64$ for $20 \mathrm{~d}$ cells; $n=40$ for adult cells).

\section{Statistical analyses}

All data are reported as the mean \pm S.E.M; $n$ denotes the number of animals analyzed. The statistical significance for $P$ value $<0.01$ was obtained with the one-way analysis of variance (ANOVA) and for $P$ value $<0.05$ with the $t$-student test (Prism 6 for Windows Version 6.01; GraphPad Software).

\section{Results}

Morphologic and cytometric characteristics of beta-cells from different postnatal ages allow their enrichment by fluorescence-activated cell sorting

To obtain beta-cell-enriched populations, pancreatic insular cells cultured from neonatal (Neo), suckling (20d), weaning (28d), and adult (Ad) rats were submitted to FACS. After using a strategy based on the beta-cell morphologic characteristics, for instance, FSC, FAD/FADH content, and SSC for cells of all the studied ages (Fig. 1A; Materials and methods), cell sorting resulted in the recovery of beta-cell-enriched populations when assessed by immunofluorescence (near to 80 and $90 \%$ of purity when immature and mature cells were used, respectively)

Published by Bioscientifica Ltd 
(Fig. 1B and C). Interestingly, we observed that the beta-cell FAD/FADH content of neonatal, suckling, and weaning rats did not display an important difference, compared with other islet cells. However, beta-cells of adult rats showed higher FAD/FADH content than the remaining islet cells (Supplementary Fig. 1, see section on supplementary data given at the end of this article).

\section{Beta-cell physiologic context during postnatal development depicted by transcriptome analysis using gene set enrichment analysis (GSEA)}

In prior work, our research group showed that the weaning period represents a critical window for postnatal, pancreatic development (Aguayo-Mazzucato et al. 2006). We performed a microarray analysis of total RNA from immature and mature beta-cells (from 20d and adult rats) to determine the transcriptome changes involved in their maturation process. An initial assessment of the global gene expression showed a high correlation among samples from the same condition (Fig. 1D). We next performed a GSEA and a leading-edge analysis to identify (1) the functional gene sets correlated with the postnatal developmental stage of animals and (2) the core genes of those sets.

GSEA yielded a list of 155 gene sets from the Molecular Signatures Database (MSigDB), including 40 gene sets from the Reactome pathway database and 64 gene sets from the Gene Ontology (GO) collection with a positive enrichment score (Table 1), and also 1055 that include 165 gene sets from the Reactome pathway database and 163 gene sets from GO collections with a negative enrichment score (Table 2). All of them showed a false discovery rate lower than 25\% and $P<0.05$ (Supplementary Table 1).

Notably, five of the top positively enriched Reactome sets consisted of genes related to beta-cells, which include: (1) regulation of gene expression in beta-cells (NES $=2.07)$, (2) regulation of insulin secretion $(\mathrm{NES}=1.94)$, (3) integration of energy metabolism (NES=1.87), (4) GABA synthesis, release, reuptake, and degradation $(\mathrm{NES}=1.85)$, and (5) regulation of beta-cell development $(\mathrm{NES}=1.80)$ (Table 1 top).

On the other hand, the top positively enriched GO sets consisted of genes related to ion channel activity that include: (1) calcium channel activity $(\mathrm{NES}=2.23)$,

(2) voltage-gated calcium channel activity $(\mathrm{NES}=2.14)$,

(3) voltage-gated cation channel activity (NES $=2.10)$, and

(4) voltage-gated channel activity $(\mathrm{NES}=2.07)$ (Table 1 bottom). Furthermore, both the negatively enriched Reactome and GO gene sets consisted of genes related to cell proliferation (Table 2).
In addition to GSEA, we performed an analysis to obtain the genes with differential expression, and we found that 438 transcripts were upregulated in adult betacells and 778 were higher in 20d beta-cells (Materials and methods and Supplementary Table 2). Differential expression analysis confirmed the results observed in the studies above. Some differentially expressed genes included adult upregulated genes such as those involved in controlling beta-cell-specific gene expression and metabolism-insulin secretion coupling (Wang et al. 2007) such as MafA, Glp1r, Aplp2, Gabbr2, and 20d upregulated genes with a critical role in cell cycle regulation such as Ccna2, Ccnb1, and Ccnb2. Moreover, we found upregulation of genes that had been suggested to be involved in beta-cell maturation, which include Slc2a2 (Navarro-Tableros et al. 2007a) and Ucn3 (Blum et al. 2012, van der Meulen et al. 2012), and others such as Gcgr, Pcsk1, Igf1, Egfr, and Kcnb2.

\section{Beta-cell transcriptome changes outline basal and GSIS maturation during postnatal development}

The leading-edge analysis of the top enriched sets, namely the Reactome regulation of insulin secretion and integration of energy metabolism, showed that genes that significantly contributed to their enrichment signal also consisted of genes related to beta-cell identity and function (Fig. 2A and Table 3). To confirm the transcriptomic changes related to maturation of insulin secretion and integration of energy metabolism, basal and stimulated (glucose 5.6 and $15.6 \mathrm{mM}$ ) GSIS of single FACS-sorted beta-cells was assessed using RHPA (Fig. 2B). We observed that weaning and adult beta-cells secreted high basal levels of insulin. This basal secretion was represented by a 1.5fold increase in the immunoplaque areas compared with suckling (20d) beta-cells, when exposed to basal glucose concentrations $(5.6 \mathrm{mM})$ (Fig. $2 \mathrm{~B}$ and $\mathrm{C}$ left panel). In addition, stimulating glucose concentrations did not produce changes on insulin secretion by neonatal betacells. However, suckling (20d), weaning (28d), and adult beta-cells showed a 1.3-, 1.2-, and 1.5-fold increase in insulin secretion, respectively (Fig. 2B and C right panel). Furthermore, the level of the response was correlated with the postnatal developmental stage of cells.

\section{T-type calcium channels, among others, could participate in beta-cell maturation}

It has been observed that voltage-gated calcium channels activity underlies insulin exocytosis and probably also contributes to the beta-cell maturation process

Published by Bioscientifica Ltd. 
Table 1 Reactome and Gene Ontology databases gene sets correlated with the adult beta-cell phenotype (with the highest positive enrichment score).

\begin{tabular}{|c|c|c|c|c|c|c|c|c|}
\hline & Name & Size & NES & $\begin{array}{l}\text { NOM } P \\
\text { value }\end{array}$ & $\begin{array}{l}\text { FDR q } \\
\text { value }\end{array}$ & $\begin{array}{l}\text { FWER } P \\
\text { value }\end{array}$ & $\begin{array}{l}\text { Rank at } \\
\max \end{array}$ & Leading edge \\
\hline \multirow[t]{12}{*}{ Reactome } & $\begin{array}{l}\text { REGULATION OF GENE } \\
\text { EXPRESSION IN BETA-CELLS }\end{array}$ & 19 & 2.07 & 0.0 & 0.0036 & 0.004 & 1492 & $\begin{array}{c}\text { Tags }=58 \%, \text { list }=11 \%, \\
\text { signal }=65 \%\end{array}$ \\
\hline & NEURONAL SYSTEM & 257 & 1.97 & 0.0 & 0.011 & 0.025 & 2382 & $\begin{array}{c}\text { Tags }=30 \%, \text { list }=17 \%, \\
\text { signal }=35 \%\end{array}$ \\
\hline & $\begin{array}{l}\text { REGULATION OF INSULIN } \\
\text { SECRETION }\end{array}$ & 83 & 1.94 & 0.0 & 0.013 & 0.044 & 1128 & $\begin{array}{c}\text { Tags }=28 \%, \text { list }=8 \%, \\
\text { signal }=30 \%\end{array}$ \\
\hline & $\begin{array}{l}\text { TRANSMISSION ACROSS } \\
\text { CHEMICAL SYNAPSES }\end{array}$ & 175 & 1.88 & 0.0 & 0.026 & 0.111 & 2335 & $\begin{array}{c}\text { Tags }=30 \%, \text { list }=17 \%, \\
\text { signal }=36 \%\end{array}$ \\
\hline & $\begin{array}{l}\text { INTEGRATION OF ENERGY } \\
\text { METABOLISM }\end{array}$ & 106 & 1.87 & 0.0 & 0.024 & 0.126 & 1128 & $\begin{array}{c}\text { Tags }=25 \%, \text { list }=8 \% \\
\text { signal }=26 \%\end{array}$ \\
\hline & $\begin{array}{l}\text { GABA SYNTHESIS RELEASE } \\
\text { REUPTAKE AND DEGRADATION }\end{array}$ & 17 & 1.85 & 0.005 & 0.028 & 0.1367 & 271 & $\begin{array}{c}\text { Tags }=29 \%, \text { list }=2 \%, \\
\text { signal }=30 \%\end{array}$ \\
\hline & POTASSIUM CHANNELS & 89 & 1.83 & 0.001 & 0.030 & 0.205 & 1947 & $\begin{array}{c}\text { Tags }=29 \%, \text { list }=14 \%, \\
\text { signal }=34 \%\end{array}$ \\
\hline & $\begin{array}{l}\text { INTERACTION BETWEEN L1 AND } \\
\text { ANKYRINS }\end{array}$ & 19 & 1.82 & 0.001 & 0.030 & 0.231 & 1961 & $\begin{array}{c}\text { Tags }=37 \%, \text { list }=14 \%, \\
\text { signal }=43 \%\end{array}$ \\
\hline & $\begin{array}{l}\text { RORA ACTIVATES CIRCADIAN } \\
\text { EXPRESSION }\end{array}$ & 20 & 1.82 & 0.001 & 0.027 & 0.231 & 3093 & $\begin{array}{c}\text { Tags }=75 \%, \text { list }=22 \%, \\
\text { signal }=96 \%\end{array}$ \\
\hline & $\begin{array}{l}\text { CIRCADIAN REPRESSION OF } \\
\text { EXPRESSION BY REV ERBA }\end{array}$ & 20 & 1.82 & 0.003 & 0.025 & 0.243 & 3093 & $\begin{array}{c}\text { Tags }=75 \%, \text { list }=22 \%, \\
\text { signal }=96 \%\end{array}$ \\
\hline & GABA RECEPTOR ACTIVATION & 48 & 1.81 & 0.001 & 0.024 & 0.254 & 2335 & $\begin{array}{c}\text { Tags }=38 \%, \text { list }=17 \%, \\
\text { signal }=45 \%\end{array}$ \\
\hline & $\begin{array}{l}\text { REGULATION OF BETA-CELL } \\
\text { DEVELOPMENT }\end{array}$ & 27 & 1.80 & 0.003 & 0.024 & 0.272 & 1875 & $\begin{array}{c}\text { Tags }=44 \%, \text { list }=13 \%, \\
\text { signal }=51 \%\end{array}$ \\
\hline \multirow[t]{12}{*}{$\begin{array}{l}\text { Gene } \\
\text { ontology }\end{array}$} & CALCIUM CHANNEL ACTIVITY & 30 & 2.23 & 0.0 & 0.0 & 0.0 & 1183 & $\begin{array}{c}\text { Tags }=40 \%, \text { list }=8 \%, \\
\text { signal }=44 \%\end{array}$ \\
\hline & $\begin{array}{l}\text { VOLTAGE-GATED CALCIUM } \\
\text { CHANNEL ACTIVITY }\end{array}$ & 17 & 2.14 & 0.0 & 0.004 & 0.001 & 1089 & $\begin{array}{c}\text { Tags }=53 \%, \text { list }=8 \%, \\
\text { signal }=57 \%\end{array}$ \\
\hline & $\begin{array}{l}\text { VOLTAGE-GATED CATION } \\
\text { CHANNEL ACTIVITY }\end{array}$ & 57 & 2.10 & 0.0 & 0.032 & 0.001 & 1914 & $\begin{array}{c}\text { Tags }=35 \%, \text { list }=14 \%, \\
\text { signal }=40 \%\end{array}$ \\
\hline & $\begin{array}{l}\text { VOLTAGE-GATED CHANNEL } \\
\text { ACTIVITY }\end{array}$ & 64 & 2.07 & 0.0 & 0.097 & 0.004 & 1121 & $\begin{array}{c}\text { Tags }=28 \%, \text { list }=8 \%, \\
\text { signal }=30 \%\end{array}$ \\
\hline & $\begin{array}{l}\text { SPHINGOLIPID METABOLIC } \\
\text { PROCESS }\end{array}$ & 27 & 2.04 & 0.0 & 0.001 & 0.009 & 1998 & $\begin{array}{c}\text { Tags }=56 \%, \text { list }=14 \%, \\
\text { signal }=65 \%\end{array}$ \\
\hline & $\begin{array}{l}\text { METAL ION TRANSMEMBRANE } \\
\text { TRANSPORTER ACTIVITY }\end{array}$ & 127 & 2.03 & 0.0 & 0.001 & 0.011 & 1947 & $\begin{array}{c}\text { Tags }=29 \%, \text { list }=14 \%, \\
\text { signal }=33 \%\end{array}$ \\
\hline & CATION CHANNEL ACTIVITY & 104 & 1.99 & 0.0 & 0.004 & 0.03 & 1947 & $\begin{array}{c}\text { Tags }=29 \%, \text { list }=14 \%, \\
\text { signal }=33 \%\end{array}$ \\
\hline & SYNAPTIC TRANSMISSION & 155 & 1.95 & 0.0 & 0.007 & 0.058 & 1999 & $\begin{array}{c}\text { Tags }=26 \%, \text { list }=14 \%, \\
\text { signal }=30 \%\end{array}$ \\
\hline & NEURON DEVELOPMENT & 55 & 1.94 & 0.0 & 0.007 & 0.066 & 1173 & $\begin{array}{c}\text { Tags }=29 \%, \text { list }=8 \%, \\
\text { signal }=32 \%\end{array}$ \\
\hline & GATED CHANNEL ACTIVITY & 108 & 1.91 & 0.0 & 0.011 & 0.109 & 1121 & $\begin{array}{c}\text { Tags }=22 \%, \text { list }=8 \%, \\
\text { signal }=24 \%\end{array}$ \\
\hline & $\begin{array}{l}\text { TRANSMISSION OF NERVE } \\
\text { IMPULSE }\end{array}$ & 168 & 1.89 & 0.0 & 0.014 & 0.147 & 1999 & $\begin{array}{c}\text { Tags }=26 \%, \text { list }=15 \%, \\
\text { signal }=29 \%\end{array}$ \\
\hline & METAL ION TRANSPORT & 100 & 1.89 & 0.0 & 0.014 & 0.163 & 2144 & $\begin{array}{c}\text { Tags }=32 \%, \text { list }=15 \%, \\
\text { signal }=37 \%\end{array}$ \\
\hline
\end{tabular}

Columns represent the name and size of the gene set; the normalized enrichment score (NES), the nominal $P$ value (NOM $P$ value), the false discovery rate $q$ value (FDR $q$ value), the family-wise error rate (FWER $P$ value), the position in the ranked list at which the maximum enrichment score occurred (RANK AT MAX), and the statistics used to define the leading-edge subset (LEADING EDGE).

(C) 2016 Society for Endocrinology Printed in Great Britain 
Table 2 Reactome and Gene Ontology databases gene sets correlated with the suckling beta-cell phenotype (with the lowest enrichment score).

\begin{tabular}{|c|c|c|c|c|c|c|c|c|}
\hline & Name & Size & NES & $\begin{array}{l}\text { NOM } P \\
\text { value }\end{array}$ & $\begin{array}{l}\text { FDR q } \\
\text { value }\end{array}$ & $\begin{array}{l}\text { FWER } P \\
\text { value }\end{array}$ & $\begin{array}{l}\text { Rank at } \\
\max \end{array}$ & Leading edge \\
\hline \multirow[t]{12}{*}{ Reactome } & DNA REPLICATION & 160 & -3.01 & 0.0 & 0.0 & 0.0 & 1450 & $\begin{array}{c}\text { Tags }=52 \%, \text { list }=10 \%, \\
\text { signal }=57 \%\end{array}$ \\
\hline & MITOTIC M-M-G1 PHASES & 140 & -2.96 & 0.0 & 0.0 & 0.0 & 1450 & $\begin{array}{c}\text { Tags }=53 \%, \text { list }=10 \%, \\
\text { signal }=58 \%\end{array}$ \\
\hline & CELL CYCLE & 315 & -2.95 & 0.0 & 0.0 & 0.0 & 1386 & $\begin{array}{c}\text { Tags }=42 \%, \text { list }=10 \%, \\
\text { signal }=45 \%\end{array}$ \\
\hline & CELL CYCLE MITOTIC & 262 & -2.91 & 0.0 & 0.0 & 0.0 & 1450 & $\begin{array}{c}\text { Tags }=42 \%, \text { list }=10 \%, \\
\text { signal }=46 \%\end{array}$ \\
\hline & MITOTIC PROMETAPHASE & 67 & -2.76 & 0.0 & 0.0 & 0.0 & 599 & $\begin{array}{c}\text { Tags }=48 \%, \text { list }=4 \%, \\
\text { signal }=50 \%\end{array}$ \\
\hline & CELL CYCLE CHECKPOINTS & 100 & -2.67 & 0.0 & 0.0 & 0.0 & 2363 & $\begin{array}{c}\text { Tags }=58 \%, \text { list }=17 \%, \\
\text { signal }=69 \%\end{array}$ \\
\hline & G2-M CHECKPOINTS & 39 & -2.57 & 0.0 & 0.0 & 0.0 & 1201 & $\begin{array}{c}\text { Tags }=62 \%, \text { list }=9 \%, \\
\text { signal }=67 \%\end{array}$ \\
\hline & CHROMOSOME MAINTENANCE & 74 & -2.55 & 0.0 & 0.0 & 0.0 & 1252 & $\begin{array}{c}\text { Tags }=49 \%, \text { list }=9 \% \\
\text { signal }=53 \%\end{array}$ \\
\hline & G1-S TRANSITION & 96 & -2.55 & 0.0 & 0.0 & 0.0 & 1809 & $\begin{array}{c}\text { Tags }=52 \%, \text { list }=13 \%, \\
\text { signal }=59 \%\end{array}$ \\
\hline & $\begin{array}{l}\text { DEPOSITION OF NE CENPA } \\
\text { CONTAINING NUCLEOSOMES } \\
\text { AT THE CENTROMERE }\end{array}$ & 27 & -2.54 & 0.0 & 0.0 & 0.0 & 626 & $\begin{array}{c}\text { Tags }=70 \%, \text { list }=4 \% \\
\text { signal }=73 \%\end{array}$ \\
\hline & MITOTIC G1-G1-S PHASES & 114 & -2.53 & 0.0 & 0.0 & 0.0 & 1914 & $\begin{array}{c}\text { Tags }=48 \%, \text { list }=14 \%, \\
\text { signal }=55 \%\end{array}$ \\
\hline & S PHASE & 99 & -2.50 & 0.0 & 0.0 & 0.0 & 1809 & $\begin{array}{c}\text { Tags }=48 \%, \text { list }=13 \%, \\
\text { signal }=55 \%\end{array}$ \\
\hline \multirow[t]{12}{*}{$\begin{array}{l}\text { Gene } \\
\text { ontology }\end{array}$} & CHROMOSOME & 101 & -2.64 & 0.0 & 0.0 & 0.0 & 704 & $\begin{array}{c}\text { Tags }=31 \%, \text { list }=5 \%, \\
\text { signal }=32 \%\end{array}$ \\
\hline & MITOTIC CELL CYCLE & 132 & -2.56 & 0.0 & 0.0 & 0.0 & 1269 & $\begin{array}{c}\text { Tags }=33 \%, \text { list }=9 \%, \\
\text { signal }=36 \%\end{array}$ \\
\hline & M PHASE OF MITOTIC CELL CYCLE & 71 & -2.55 & 0.0 & 0.0 & 0.0 & 1269 & $\begin{array}{c}\text { Tags }=39 \%, \text { list }=9 \%, \\
\text { signal }=43 \%\end{array}$ \\
\hline & $\begin{array}{l}\text { CHROMOSOME PERICENTRIC } \\
\text { REGION }\end{array}$ & 26 & -2.55 & 0.0 & 0.0 & 0.0 & 368 & $\begin{array}{c}\text { Tags }=50 \%, \text { list }=3 \% \\
\text { signal }=51 \%\end{array}$ \\
\hline & SPINDLE & 34 & -2.51 & 0.0 & 0.0 & 0.0 & 368 & $\begin{array}{c}\text { Tags }=41 \%, \text { list }=3 \%, \\
\text { signal }=42 \%\end{array}$ \\
\hline & MITOSIS & 68 & -2.51 & 0.0 & 0.0 & 0.0 & 1269 & $\begin{array}{c}\text { Tags }=40 \%, \text { list }=9 \%, \\
\text { signal }=43 \%\end{array}$ \\
\hline & M PHASE & 95 & -2.49 & 0.0 & 0.0 & 0.0 & 1269 & $\begin{array}{c}\text { Tags }=36 \%, \text { list }=9 \% \\
\text { signal }=38 \%\end{array}$ \\
\hline & CHROMOSOMAL PART & 77 & -2.48 & 0.0 & 0.0 & 0.0 & 704 & $\begin{array}{c}\text { Tags }=31 \%, \text { list }=5 \%, \\
\text { signal }=39 \%\end{array}$ \\
\hline & CELL CYCLE PROCESS & 167 & -2.47 & 0.0 & 0.0 & 0.0 & 1269 & $\begin{array}{c}\text { Tags }=32 \%, \text { list }=9 \%, \\
\text { signal }=34 \%\end{array}$ \\
\hline & CELL CYCLE PHASE & 145 & -2.45 & 0.0 & 0.0 & 0.0 & 1269 & $\begin{array}{c}\text { Tags }=32 \%, \text { list }=9 \%, \\
\text { signal }=35 \%\end{array}$ \\
\hline & CHROMOSOME SEGREGATION & 26 & -2.32 & 0.0 & 0.0 & 0.0 & 770 & $\begin{array}{c}\text { Tags }=46 \%, \text { list }=5 \%, \\
\text { signal }=49 \%\end{array}$ \\
\hline & KINETOCHORE & 21 & -2.27 & 0.0 & 0.0 & 0.0 & 271 & $\begin{array}{c}\text { Tags }=43 \%, \text { list }=2 \%, \\
\text { signal }=44 \%\end{array}$ \\
\hline
\end{tabular}

Columns represent the name and size of the gene set; the normalized enrichment score (NES), the nominal P value (NOM p-val), the false discovery rate q value (FDR q-val), the family-wise error rate (FWER p-val), the position in the ranked list at which the maximum enrichment score occurred (RANK AT MAX), and the statistics used to define the leading-edge subset (LEADING EDGE).

(C) 2016 Society for Endocrinology Printed in Great Britain 
A
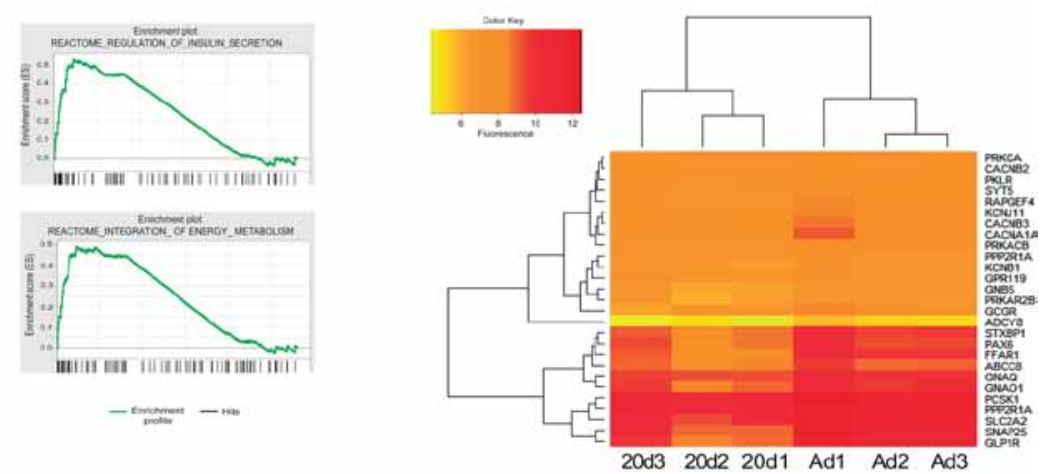

B

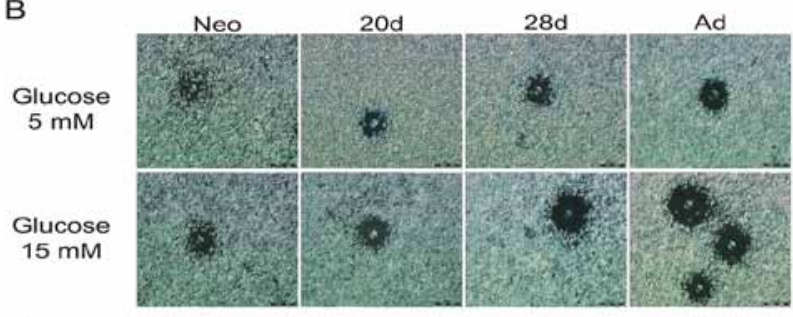

C

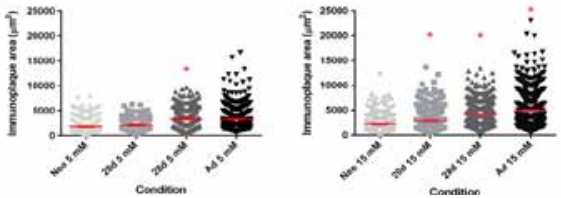

Figure 2

Basal and glucose-induced insulin secretionrelated expression and physiologic changes observed in beta-cells and involved in their maturation process. (A) Enrichment plots of the Reactome regulation of insulin secretion and the Reactome integration of energy metabolism gene sets that show the running sum for each set within the beta-cell dataset (green line), and the leading-edge subset of enriched genes (vertical black lines). Heatmap of the leading-edge core genes based on their expression levels, and dendrogram depicting similarities among samples. (B) Representative images of the hemolytic immunoplaques produced by insulin secretion of neonate, suckling, weaning, and adult sorted beta-cells, incubated at basal $(5.6 \mathrm{mM}$ glucose; top panel) and stimulating (15.6 mM glucose; bottom panel) conditions. (C) Quantification of immunoplaque areas observed in basal (left graph) and stimulating (right graph) conditions. Red bars represent the mean + s.E.m. Scale bar $=50 \mu \mathrm{m} .+P<0.01$ vs the previous age, $* P<0.01$ vs the same age at $5.6 \mathrm{mM}$ glucose.

Table 3 List of genes that contribute to the leading-edge subset within the Reactome regulation of insulin secretion gene set.

\begin{tabular}{l}
\hline Gene symbol \\
\hline Glp1r \\
Snap25 \\
Ffar1 \\
Slc2a2 \\
Pcsk1 \\
Rapgef4 \\
Stxbp1 \\
Adcy8 \\
Cacna1a \\
Gnao1 \\
\\
Cacnb3 \\
Prkca \\
Kcnj11 \\
Cacnb2 \\
Prkacb \\
Prkar2b \\
Gnb5 \\
Syt5 \\
Pax6 \\
Abcc8 \\
Kcnb1 \\
Gpr119 \\
Gnaq \\
\hline
\end{tabular}

\section{Gene title}

Glucagon-like peptide 1 receptor

Synaptosomal-associated protein, $25 \mathrm{kDa}$

Free fatty acid receptor 1

Solute carrier family 2 (facilitated glucose transporter), member 2

Proprotein convertase subtilisin/kexin type 1

Rap guanine nucleotide exchanger factor (GEF) 4

Syntaxin binding protein 1

Adenylate cyclase 8 (brain)

Calcium channel, voltage-dependent, P/Q type, alpha 1 A subunit

Guanine nucleotide-binding protein (G protein), alpha activating activity polypeptide $\mathrm{O}$

Calcium channel, voltage-dependent, beta 3 subunit

Protein kinase $\mathrm{C}$, alpha

Potassium inwardly rectifying cannel, subfamily J, member 11

Calcium channel, voltage-dependent, beta 2 subunit

Protein kinase, CAMP-dependent, catalytic, beta

Protein kinase, CAMP-dependent, regulatory, type II, beta

Guanine nucleotide binding protein (G protein), beta 5

Synaptotagmin V

Paired box gene 6 (aniridia, keratitis)

ATP-binding cassette, subfamily C (CFTR/MRP), member 8

Potassium voltage-gated channel, Shab-related subfamily, member 1

G protein-coupled receptor 119

Guanine nucleotide-binding protein (G protein), 1 polypeptide

\begin{tabular}{c}
$\begin{array}{c}\text { Rank in } \\
\text { gene list }\end{array}$ \\
\hline 22 \\
38 \\
100 \\
180 \\
199 \\
259 \\
271 \\
280 \\
314 \\
346 \\
\\
387 \\
473 \\
633 \\
644 \\
647 \\
691 \\
704 \\
708 \\
758 \\
873 \\
1071 \\
1110 \\
1128 \\
\hline
\end{tabular}

Running ES

0.051268473

0.09826441

0.1336413

0.16236971

0.19445017

0.22046465

0.24929762

0.27789912

0.30345398

0.3279428

0.35045815

0.3679656

0.37741008

0.3973513

0.41785166

0.4347977

0.4537127

0.47325456

0.48886296

0.4985865

0.5006605

0.51376957

0.5282689

Detailing its position, the score used to position the gene, and the enrichment score at this point in the ranked list of genes within the beta-cell dataset. Columns represent the gene symbol, the name of the gene, the position of the gene in the ranked list of genes, the score used to position the gene in the ranked list, and the enrichment score at this point in the ranked list of genes. 
Table 4 List of genes that contribute to the leading-edge subset within the GO calcium channel activity gene set.

\begin{tabular}{l} 
Gene symbol \\
\hline Trpc5 \\
Cacna2d1 \\
Cacna1c \\
Cacna1b \\
Cacna1h \\
Cacna1a \\
Cacnb3 \\
Cacnb2 \\
Trpc1 \\
Cacna1d \\
Cacnb1 \\
Ms4a2
\end{tabular}

\begin{tabular}{l} 
Gene title \\
\hline Transient receptor potential cation channel, subfamily C, member 5 \\
Calcium channel, voltage-dependent, alpha $2 /$ delta subunit 1 \\
Calcium channel, voltage-dependent, L type, alpha 1 C subunit \\
Calcium channel, voltage-dependent, L type, alpha $1 \mathrm{~B}$ subunit \\
Calcium channel, voltage-dependent, alpha $1 \mathrm{H}$ subunit \\
Calcium channel, voltage-dependent, P/Q type, alpha $1^{\text {a }}$ subunit \\
Calcium channel, voltage-dependent, beta 3 subunit \\
Calcium channel, voltage-dependent, beta 2 subunit \\
Transient receptor potential cation channel, subfamily C, member 1 \\
Calcium channel, voltage-dependent, L type, alpha 1 D subunit \\
Calcium channel, voltage-dependent, beta 1 subunit \\
Membrane-spanning 4-domains, subfamily A, member 2 (Fc fragment \\
of IgE, high affinity I, receptor for; beta polypeptide)
\end{tabular}

\begin{tabular}{c}
$\begin{array}{c}\text { Rank in } \\
\text { gene list }\end{array}$ \\
\hline 42 \\
55 \\
206 \\
260 \\
294 \\
314 \\
387 \\
644 \\
716 \\
799 \\
1089 \\
1183 \\
\hline
\end{tabular}

\begin{tabular}{ccc}
$\begin{array}{c}\text { Rank metric } \\
\text { score }\end{array}$ & & Running ES \\
\cline { 1 - 1 } 0.489 & & 0.1158 \\
0.472 & & 0.2295 \\
0.343 & & 0.3021 \\
0.313 & & 0.3743 \\
0.297 & & 0.4442 \\
0.290 & & 0.5132 \\
0.263 & & 0.5720 \\
0.215 & & 0.6059 \\
0.204 & & 0.6504 \\
0.194 & & 0.6915 \\
0.166 & & 0.7114 \\
0.158 & & 0.7433 \\
& &
\end{tabular}

We detailed its place, the score used to position the gene, and the enrichment score at this point in the ranked list of genes within the beta-cell dataset. Columns represent the gene symbol, the name of the gene, the position of the gene in the ranked list of genes, the score used to position the gene in the ranked list, and the enrichment score at this point in the ranked list of genes.

(Navarro-Tableros et al. 2007b). We considered the top enriched GO gene sets (Table 4) further to investigate the phenotype correlation of the Cacna1h gene with maturation (Fig. 3A). We performed whole-cell recordings of macroscopic calcium currents from cultured, immature (20d), and mature (adult) beta-cells. Both immature and mature cells showed T-type calcium currents, within the expected membrane potential interval, from -40 to $-10 \mathrm{mV}$ (Fig. 3B) (Materials and methods). Furthermore, we observed that $85 \%$ of adult beta-cells showed T-type calcium currents compared with $59 \%$ of $20 \mathrm{~d}$ beta-cells (Fig. 3C).

\section{Acquisition of a mature beta-cell phenotype involves the loss of replicative capabilities}

As shown in Table 2, the Reactome and GO databases' bottom-enriched sets are related to cell proliferation. Thus, we first assessed beta-cell proliferation from suckling rats by Ki67 immunofluorescence and observed a low proliferation rate (data not shown). However, the leading-edge analysis results consisted of genes related to cell cycle progressions such as E2F1, Tp53, Ccna2, and Ccnb1 (Fig. 4A top panel and Table 5). Moreover, some of these core genes showed changes in their expression levels (Fig. 4A lower panel). Accordingly, with these results, we investigated the distribution of the cell cycle phases within suckling, weaning, and adult beta-cells by flow cytometry (Fig. 4B). We observed, on one hand, that the proportion of adult beta-cells at G1 cell cycle phase (87.9\%) was higher compared with suckling (20d) and weaning (28d) beta-cells (79.1\% for both). On the other hand, the percentage of weaning (28d) and adult betacells at $S$ phase (2.12 and $0.65 \%$, respectively), and that of adult cells at $\mathrm{G} 2 / \mathrm{M}$ phase $(11.4 \%)$, decreased when compared with suckling (20d) beta-cells (16.1\% for G2/M, and $4.6 \%$ for $\mathrm{S}$ phase of the cell cycle) (Fig. 4C, see asterisks at insets, and Fig. 4D).

\section{Discussion}

Postnatal maturation of pancreatic beta-cells is an important research area due to the increasing interest in the in vitro generation of insulin-secreting cells to treat both type 1 and type 2 diabetes mellitus. Previous works had shown that a physiological critical window that consists of the suckling and weaning periods plays a significant role in rat beta-cell development and lifespan function (Aguayo-Mazzucato et al. 2006, CabreraVasquez et al. 2009, Stolovich-Rain et al. 2015). Research on the development, including the postnatal period, of pancreatic beta-cells could generate significant knowledge to, on one hand, improve the generation of mature insulin-producing cells as a source for diabetes cell-based therapies and, on the other hand, to stimulate in situ beta-cell division to overcome insulin deficiency observed during diabetes.

Fluorescence-activated cell sorting is a useful tool to study a wide variety of biological processes in a particular type of cell. In previous work, different research groups used this approach to study beta-cells obtained from adult rats (Pipeleers et al. 1985, Kohler et al. 2012) and, recently, from neonatal rats (Martens et al. 2014).

Published by Bioscientifica Ltd 
A

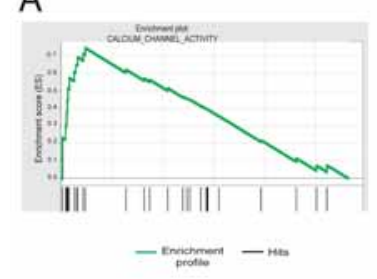

B
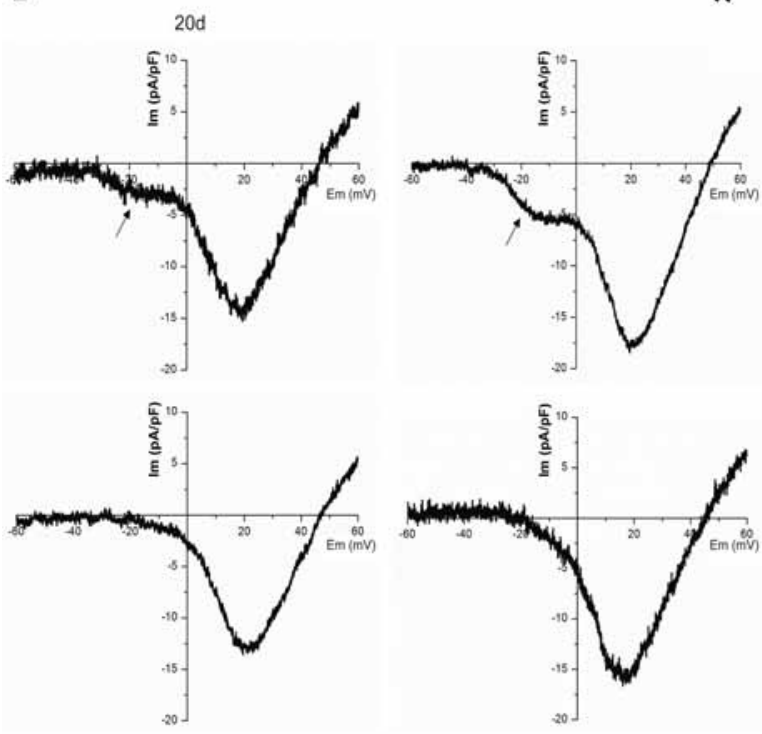

C

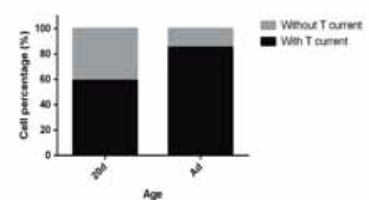

In the present work, we purified and cultured pancreatic beta-cells from rats between postnatal day 1 and 10 weeks old, isolated by flow cytometry. We observed that the more mature the cells were, the higher the beta-cell purity yield we obtained. This fact could be related to the gradual acquisition of certain morphologic characteristics such as size (FSC), internal complexity (SSC), and autofluorescence (FITC) during early postnatal development, which could probably identify a beta-cell among others within the mature pancreatic islet (Supplementary Fig. 1). For instance, we consider that FACS consists of a valuable tool for culturing enriched beta-cell populations compared with those obtained from primary cultures.

\section{Figure 3}

Calcium channels expression and functional changes that contribute, in part, to the maturation of basal and glucose-induced insulin secretion observed in beta-cells. (A) Enrichment plot of the GO calcium channel activity gene set that show the running sum for the set within the beta-cell dataset (green line), and the leadingedge subset of enriched genes (vertical black lines). Heat map of the leading-edge core genes based on their expression levels and a dendrogram is depicting similarities among samples. (B) Representative recordings of global calcium channel currents observed in $20 \mathrm{~d}$ and adult beta-cells. Arrows represent T-type calcium channel current. (C) Quantification of the beta-cell percentage with and without T-type calcium channel current (gray: percentage of cells without T-type calcium current; black: percentage of cells with T-type calcium current). A full colour version of this figure is available at http://dx.doi. org/10.1530/JME-16-0052.
Gene-set, enrichment-based transcriptome analysis provides a large list of curated gene sets that not only shows the top-ranked signaling pathways, functions, or processes that are enriched in a correlated manner with a specific cell phenotype but also allows a comparison with those whose changes during development could contribute the most to the phenotype acquisition. First, we performed a GSEA to outline the gene sets that characterize mature beta-cell physiology. Interestingly, we obtained a list of 155 gene sets that include some that could be expected beta-cell maturity-related sets, such as regulation of gene expression in beta-cells, regulation of beta-cell development, and insulin secretion. Also, we obtained 
A

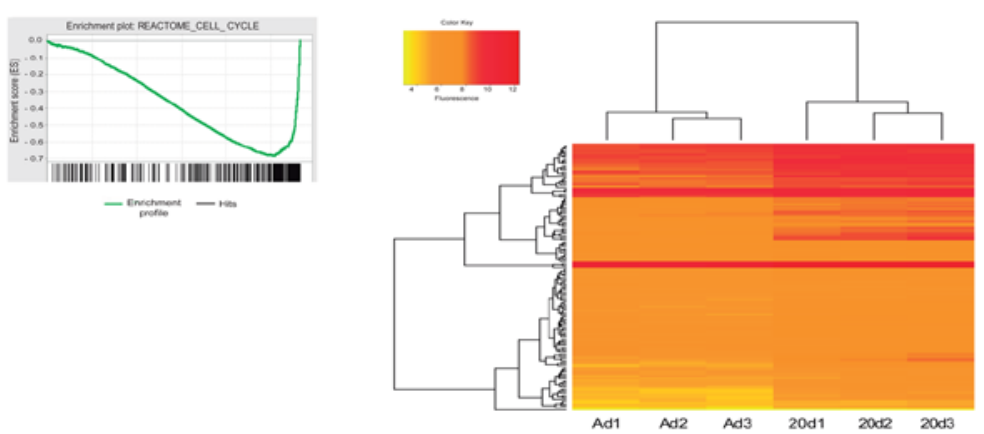

B

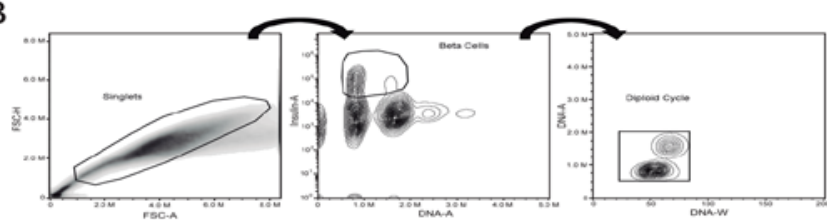

C
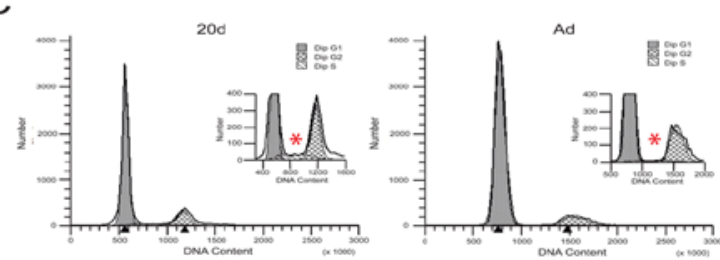

D

Table 5 List of genes that contribute to the leading-edge subset within the Reactome cell cycle gene set.

\begin{tabular}{l}
\hline Gene symbol \\
\hline Bub1b \\
Mybl2 \\
Dsn1 \\
Kif2c \\
Kif18a \\
Cdc20 \\
Mad2I1 \\
Ccnb2 \\
Gins1 \\
Pttg1 \\
Plk1 \\
Hist1h2bb \\
Mlf1ip \\
Cenpi \\
Ccnb1 \\
Nuf2 \\
Ska1 \\
Spc25 \\
Ccna2 \\
Sgol2 \\
Ndc80 \\
Rrm2 \\
Cenpk \\
Cdk1 \\
Bub1 \\
\hline
\end{tabular}

\section{Gene title}

BUB1 budding uninhibited by benzimidazoles 1 homolog beta (yeast) V-myb myeloblastosis viral oncogene homolog (avian)-like 2

DSN1, MIND kinetochore complex component, homolog (S. cerevisiae)

Kinesin family member $2 \mathrm{C}$

Kinesin family member $18 \mathrm{~A}$

CDC20 cell division cycle 20 homolog (S. cerevisiae)

MAD2 mitotic arrest deficient-like 1 (yeast)

Cyclin B2

GINS complex subunit 1 (Psf1 homolog)

Pituitary tumor-transforming 1

Polo-like kinase 1 (Drosophila)

Histone cluster 1, H2bb

MLF1-interacting protein

Centromere protein I

Cyclin B1

NUF2, NDC80 kinetochore complex component, homolog (S. cerevisiae)

Spindle and kinetochore associated complex subunit 1

SPC25, NDC80 kinetochore complex component, homolog (S. cerevisiae)

Cyclin A2

Shugoshin-like 2 (S. pombe)

NDC80 homolog, kinetochore complex component (S. cerevisiae)

Ribonucleotide reductase M2 polypeptide

Centromere protein $\mathrm{K}$

Cyclin-dependent kinase 1

BUB1 budding uninhibited by benzimidazoles 1 homolog (yeast)

\begin{tabular}{c}
$\begin{array}{c}\text { Rank in } \\
\text { gene list }\end{array}$ \\
\hline 13,991 \\
13,999 \\
14,008 \\
14,010 \\
14,017 \\
14,018 \\
14,019 \\
14,020 \\
14,023 \\
14,028 \\
14,036 \\
14,037 \\
14,039 \\
14,047 \\
14,056 \\
14,062 \\
14,065 \\
14,074 \\
14,078 \\
14,080 \\
14,083 \\
14,085 \\
14,090 \\
14,092 \\
14,094 \\
\hline
\end{tabular}

\begin{tabular}{c}
\hline $\begin{array}{c}\text { Rank metric } \\
\text { score }\end{array}$ \\
\hline-0.503589034 \\
-0.523670435 \\
-0.549398065 \\
-0.563030958 \\
-0.576656222 \\
-0.580106974 \\
-0.580602169 \\
-0.581152618 \\
-0.603614151 \\
-0.619677007 \\
-0.640498042 \\
-0.644302547 \\
-0.64978236 \\
-0.678234518 \\
-0.691223979 \\
-0.717477024 \\
-0.734317064 \\
-0.804355443 \\
-0.842607439 \\
-0.846453488 \\
-0.873560488 \\
-0.922827721 \\
\\
-0.932636738 \\
-0.986617088 \\
\hline
\end{tabular}

Running ES

$-0.2868474$

$-0.27833852$

$-0.26945922$

$-0.2598374$

$-0.25034368$

$-0.2403553$

$-0.2303584$

$-0.22035204$

$-0.21010399$

$-0.19972445$

$-0.189204$

$-0.17811032$

$-0.1669948$

$-0.15582462$

$-0.14450333$

$-0.13251238$

$-0.12001387$

$-0.13674466$

$-0.09245413$

$-0.0779523$

$-0.06305628$

$-0.048064876$

$-0.03246564$

$-0.016479896$

4.35E-04

Detailing its place, the score used to position the gene, and the enrichment score at this point in the ranked list of genes within the beta-cell dataset. Columns represent the gene symbol, the name of the gene, the position of the gene in the ranked list of genes, the score used to position the gene in the ranked list, and the enrichment score at this point in the ranked list of genes.

http://jme.endocrinology-journals.org DOI: 10.1530/JME-16-0052
C 2016 Society for Endocrinology Printed in Great Britain
Published by Bioscientifica Ltd 
new beta-cell maturity-related gene sets, such as potassium channel activity, sphingolipid metabolism, transmission across chemical synapses, and miRNA-30 target genes (Supplementary Tables 1, 3, and 4).

Our validation approach confirmed that mature beta-cells contain fully developed secretory machinery and integrate metabolic inputs in a more efficient manner. Recent work had shown that sphingosine kinase 2 (Sphk2) activation and a rise in S1P levels due to glucose stimulation play an important role in GSIS. Thus, further research on this new beta-cell maturityrelated gene set would be needed to assess their role in the beta-cell maturation process (Cantrell Stanford et al. 2012). Moreover, a different research group had suggested that miR-30 family microRNAs maintain the epithelial phenotype of pancreatic islet cells (Joglekar et al. 2009) though it would also be interesting to assess their role in the beta-cell postnatal development and the GSIS. Finally, it has been demonstrated that the molecular machinery of insulin exocytosis in beta-cells consists of a variety of proteins very similar to that observed in synaptic vesicle release (Hou et al. 2009). However, the physiologic role of these proteins during beta-cell maturation remains unknown, and further work is needed.

GSEA also yielded a large list of gene sets whose decreased activity could be associated with the loss of a replicating and immature phenotype. We decided to validate these observations using flow cytometry analysis to determine the distribution of the cycle phases within beta-cell populations obtained from suckling, weaning, and adult rats.

A recent work analyzed the cell cycle progression using the Fucci system in transformed fetal human pancreatic beta-cell lines. Their results showed that the induction of advanced differentiation is correlated with the exit from the cell cycle of these cells (Carlier et al. 2014). Our results showed that immature beta-cells actively transcribe proliferation-related genes and that a higher percentage of beta-cells from suckling and weaning rats could be found at $S$ and $\mathrm{G} 2 / \mathrm{M}$ phases of the cell cycle when compared with beta-cells from adult rats. However, the majority of beta-cells at all ages were found at the G1/G0 phase. Although postnatal beta-cell replication and apoptosis have been described before (Scaglia et al. 1997, Kulkarni et al. 2012), to our knowledge, this is the first work that analyzes primary cultured rat beta-cell progression among the cell cycle phases during rat postnatal maturation.

Moreover, Annicote and coworkers observed that some canonical cell-cycle-related gene products such as CDK4, pRB, and E2F1 could be involved in the transcriptional regulation of insulin secretion-related genes such as Kcnj11 (Kir6.2, which is a component of the KATP channel). Also, they demonstrated that the CDK4-pRB-E2F1 pathway could be regulated by insulin signaling in mouse pancreatic islets (Annicotte et al. 2009). This observation could explain in part why beta-cells from suckling rats show low proliferation rates (tested by Ki67 immunofluorescence, data not shown) despite their high expression of cell-cycle-related genes, indicating that the beta-cells' proliferative capability is inversely correlated with the basal robust insulin secretion and the glucosestimulated insulin secretion functions.

To our knowledge, our lab was the first to propose the weaning period as a critical maturation window of pancreatic development, and suggest that dietary changes in carbohydrates and lipids composition play a highlighting role in GSIS maturation (Aguayo-Mazzucato et al. 2006). Furthermore, recent work has observed that mice prematurely weaned to a high-fat diet resembling milk showed a lower increase in plasma insulin in response to glucose compared with mice prematurely weaned to a normal chow diet (Stolovich-Rain et al. 2015). These data point to the leading role of diet over age in the maturation of the beta-cell GSIS.

This work highlights the relevance of the molecular machinery of insulin exocytosis and the cell cycle pathway roles in the maturation process of pancreatic betacells. Moreover, future work to elucidate pathways that could control either the role of these exocytic proteins or the cell cycle proteins will bring new opportunities to expand beta-cell populations to treat diabetes.

\section{Supplementary data}

This is linked to the online version of the paper at http://dx.doi.org/10.1530/ JME-16-0052.

Declaration of interest

The authors declare that there is no conflict of interest that could be perceived as prejudicing the impartiality of the research reported.

\section{Funding}

This work was supported by Dirección General de Asuntos del Personal Académico (DGAPA)-UNAM Grant IN-213114 to M Hiriart, Grant IV-100116 to Alejandro Frank Hoeflich, and Consejo Nacional de Ciencia y Tecnología (CONACyT-México) grant CB2009-131647 to M Hiriart. C Larqué had a CONACYT doctoral fellowship. Data in this work are part of his doctoral dissertation in the Posgrado en Ciencias Biomédicas de la Universidad Nacional Autónoma de México. http://jme.endocrinology-journals.org DOI: 10.1530/JME-16-0052
() 2016 Society for Endocrinology Printed in Great Britain
Published by Bioscientifica Ltd 


\section{Acknowledgements}

We thank Dr Erandi Ayala for technical assessment and Dr Félix Recillas Targa for discussing results of this work; Carmen Sánchez-Soto for assistance in animal care and experiments; Claudia Rivera-Cerecedo and animal facility of IFC-UNAM for providing animal management and care. We are also grateful to the Microscopy and Computer units of IFC-UNAM, in particular to Francisco Pérez and Ana María Escalante for their technical support. We also thank Carlos Castellanos and the Cytofluorometry Unit of the Instituto de Ciencias Biomédicas UNAM. Finally, we thank Fabiola Morales Mandujano, M C Raúl Mojica Espinosa, Dr Marcela Lilian Varela Gómez, and the Microarray Unit from the Instituto Nacional de Medicina Genómica, Mexico.

\section{References}

Aguayo-Mazzucato C, Sanchez-Soto C, Godinez-Puig V, GutierrezOspina G \& Hiriart M 2006 Restructuring of pancreatic islets and insulin secretion in a postnatal critical window. PLOS ONE 1 e35. (doi:10.1371/journal.pone.0000035)

Aguayo-Mazzucato C, Koh A, El Khattabi I, Li WC, Toschi E, Jermendy A, Juhl K, Mao K, Weir GC, Sharma A, et al. 2011 Mafa expression enhances glucose-responsive insulin secretion in neonatal rat beta cells. Diabetologia 54 583-593. (doi:10.1007/ s00125-010-2026-z)

Annicotte JS, Blanchet E, Chavey C, Iankova I, Costes S, Assou S, Teyssier J, Dalle S, Sardet C \& Fajas L 2009 The CDK4-pRB-E2F1 pathway controls insulin secretion. Nature Cell Biology 11 1017-1023. (doi:10.1038/ncb1915)

Blum B, Hrvatin SS, Schuetz C, Bonal C, Rezania A \& Melton DA 2012 Functional beta-cell maturation is marked by an increased glucose threshold and by expression of urocortin 3. Nature Biotechnology 30 261-264. (doi:10.1038/nbt.2141)

Cabrera-Vasquez S, Navarro-Tableros V, Sanchez-Soto C, GutierrezOspina G \& Hiriart M 2009 Remodelling sympathetic innervation in rat pancreatic islets ontogeny. BMC Developmental Biology 934. (doi:10.1186/1471-213X-9-34)

Cantrell Stanford J, Morris AJ, Sunkara M, Popa GJ, Larson KL \& Ozcan S 2012 Sphingosine 1-phosphate (S1P) regulates glucose-stimulated insulin secretion in pancreatic beta cells. Journal of Biological Chemistry 287 13457-13464. (doi:10.1074/ jbc.M111.268185)

Carlier G, Maugein A, Cordier C, Pechberty S, Garfa-Traore M, Martin P, Scharfmann R \& Albagli O 2014 Human fucci pancreatic Beta cell lines: new tools to study Beta cell cycle and terminal differentiation. PLOS ONE 9 e108202. (doi:10.1371/journal. pone.0108202)

D'Amour KA, Bang AG, Eliazer S, Kelly OG, Agulnick AD, Smart NG, Moorman MA, Kroon E, Carpenter MK \& Baetge EE 2006 Production of pancreatic hormone-expressing endocrine cells from human embryonic stem cells. Nature Biotechnology 24 1392-1401. (doi:10.1038/nbt1259)

Gentleman RC, Carey VJ, Bates DM, Bolstad B, Dettling M, Dudoit S, Ellis B, Gautier L, Ge Y, Gentry J, et al. 2004 Bioconductor: open software development for computational biology and bioinformatics. Genome Biology 5 R80. (doi:10.1186/ gb-2004-5-10-r80)

Hamill OP, Marty A, Neher E, Sakmann B \& Sigworth FJ 1981 Improved patch-clamp techniques for high-resolution current recording from cells and cell-free membrane patches. Pflügers Archiv 391 85-100. (doi:10.1007/BF00656997)

Hiriart M \& Aguilar-Bryan L 2008 Channel regulation of glucose sensing in the pancreatic beta-cell. American Journal of Physiology: Endocrinology and Metabolism 295 E1298-E1306. (doi:10.1152/ ajpendo.90493.2008)
Hou JC, Min L \& Pessin JE 2009 Insulin granule biogenesis, trafficking and exocytosis. Vitamins \& Hormones 80 473-506. (doi:10.1016/ S0083-6729(08)00616-X)

Hrvatin S, O'Donnell CW, Deng F, Millman JR, Pagliuca FW, DiIorio P, Rezania A, Gifford DK \& Melton DA 2014 Differentiated human stem cells resemble fetal, not adult, beta cells. PNAS 111 3038-3043. (doi:10.1073/pnas.1400709111)

Jermendy A, Toschi E, Aye T, Koh A, Aguayo-Mazzucato C, Sharma A, Weir GC, Sgroi D \& Bonner-Weir S 2011 Rat neonatal beta cells lack the specialised metabolic phenotype of mature beta cells. Diabetologia 54 594-604. (doi:10.1007/s00125-010-2036-x)

Joglekar MV, Patil D, Joglekar VM, Rao GV, Reddy DN, Mitnala S, Shouche Y \& Hardikar AA 2009 The miR-30 family microRNAs confer epithelial phenotype to human pancreatic cells. Islets $\mathbf{1}$ 137-147. (doi:10.4161/isl.1.2.9578)

Kohler M, Dare E, Ali MY, Rajasekaran SS, Moede T, Leibiger B, Leibiger IB, Tibell A, Juntti-Berggren L \& Berggren PO 2012 One-step purification of functional human and rat pancreatic alpha cells. Integrative Biology 4 209-219. (doi:10.1039/c2ib00125j)

Kulkarni RN, Mizrachi EB, Ocana AG \& Stewart AF 2012 Human beta-cell proliferation and intracellular signaling: driving in the dark without a road map. Diabetes 61 2205-2213. (doi:10.2337/ db12-0018)

Kumar SS, Alarfaj AA, Munusamy MA, Singh AJ, Peng IC, Priya SP, Hamat RA \& Higuchi A 2014 Recent developments in beta-cell differentiation of pluripotent stem cells induced by small and large molecules. International Journal of Molecular Sciences 15 23418-23447. (doi:10.3390/ijms151223418)

Martens GA, Motte E, Kramer G, Stange G, Gaarn LW, Hellemans K, Nielsen JH, Aerts JM, Ling Z \& Pipeleers D 2014 Functional characteristics of neonatal rat beta cells with distinct markers. Journal of Molecular Endocrinology 52 11-28. (doi:10.1530/ JME-13-0106)

Mayhew CN \& Wells JM 2010 Converting human pluripotent stem cells into beta-cells: recent advances and future challenges. Current Opinion in Organ Transplantation 15 54-60. (doi:10.1097/ MOT.0b013e3283337e1c)

Narayanan K, Lim VY, Shen J, Tan ZW, Rajendran D, Luo SC, Gao S, Wan AC \& Ying JY 2014 Extracellular matrix-mediated differentiation of human embryonic stem cells: differentiation to insulin-secreting beta cells. Tissue Engineering Part A 20 424-433. (doi:10.1089/ten.tea.2013.0257)

Navarro-Tableros V, Fiordelisio T, Hernandez-Cruz A \& Hiriart M $2007 a$ Nerve growth factor promotes development of glucoseinduced insulin secretion in rat neonate pancreatic beta cells by modulating calcium channels. Channels 1 408-416. (doi:10.4161/ chan.1.6.5450)

Navarro-Tableros V, Fiordelisio T, Hernandez-Cruz A \& Hiriart M 2007b Physiological development of insulin secretion, calcium channels, and GLUT2 expression of pancreatic rat beta-cells. American Journal of Physiology: Endocrinology and Metabolism292 E1018-E1029. (doi:10.1152/ajpendo.00457.2006)

Pagliuca FW, Millman JR, Gurtler M, Segel M, Van Dervort A, Ryu JH, Peterson QP, Greiner D \& Melton DA 2014 Generation of functional human pancreatic beta cells in vitro. Cell 159 428-439. (doi:10.1016/j.cell.2014.09.040)

Pipeleers DG, in't Veld PA, Van de Winkel M, Maes E, Schuit FC \& Gepts W 1985 A new in vitro model for the study of pancreatic A and B cells. Endocrinology 117 806-816. (doi:10.1210/endo-117-3-806)

Scaglia L, Cahill CJ, Finegood DT \& Bonner-Weir S 1997 Apoptosis participates in the remodeling of the endocrine pancreas in the neonatal rat. Endocrinology 138 1736-1741. (doi:10.1210/ endo.138.4.5069)

Schroeder IS 2012 Potential of pluripotent stem cells for diabetes therapy. Current Diabetes Reports 12 490-498. (doi:10.1007/ s11892-012-0292-5) 
Sena CM, Bento CF, Pereira P \& Seica R 2010 Diabetes mellitus: new challenges and innovative therapies. EPMA Journal 1 138-163. (doi:10.1007/s13167-010-0010-9)

Stolovich-Rain M, Enk J, Vikesa J, Nielsen FC, Saada A, Glaser B \& Dor Y 2015 Weaning triggers a maturation step of pancreatic beta cells. Developmental Cell 32 535-545. (doi:10.1016/j.devcel.2015.01.002) Subramanian A, Tamayo P, Mootha VK, Mukherjee S, Ebert BL, Gillette MA, Paulovich A, Pomeroy SL, Golub TR, Lander ES, et al. 2005 Gene set enrichment analysis: a knowledge-based approach for interpreting genome-wide expression profiles. PNAS $\mathbf{1 0 2}$ 15545-15550. (doi:10.1073/pnas.0506580102) van der Meulen T, Xie R, Kelly OG, Vale WW, Sander M \& Huising MO 2012 Urocortin 3 marks mature human primary and embryonic stem cell-derived pancreatic alpha and beta cells. PLOS ONE 7 e52181. (doi:10.1371/journal.pone.0052181)

Vetere A, Choudhary A, Burns SM \& Wagner BK 2014 Targeting the pancreatic beta-cell to treat diabetes. Nature Reviews Drug Discovery 13 278-289. (doi:10.1038/nrd4231)

Wang H, Brun T, Kataoka K, Sharma AJ \& Wollheim CB 2007 MAFA controls genes implicated in insulin biosynthesis and secretion. Diabetologia 50 348-358. (doi:10.1007/ s00125-006-0490-2)

Received in final form 2 May 2016

Accepted 24 May 2016

Accepted Preprint published online 24 May 2016 (c) 2016 Society for Endocrinology Printed in Great Britain
Published by Bioscientifica Ltd. 